\title{
Assessment of some heavy metals and total hydrocarbons in Clarias gariepinus fish of Osse River, Edo State, Nigeria
}

\author{
Isibor Patrick Omoregie ${ }^{1}$, Imoobe Tunde Ohiokhioya Thadeus ${ }^{2}$, Izegaegbe \\ Joshua Idowu ${ }^{3}$, Oluowo Elohor Freeman ${ }^{4}$ \\ ${ }^{1}$ (Department of Animal and Environmental Biology, University of Benin, Benin City, PMB 1154, Nigeria) \\ ${ }^{2}$ (Department of Animal and Environmental Biology, University of Benin, Benin City, PMB 1154, Nigeria) \\ 3(Department of Zoology, Ambrose Alli University, Ekpoma, Edo State, PMB 14, Nigeria) \\ ${ }^{4}$ (Department of Animal and Environmental Biology, University of Benin, Benin City, PMB 1154, Nigeria)
}

\begin{abstract}
The sequence of the heavy metals ( $\mathrm{Fe}, \mathrm{Mn}, \mathrm{Zn}, \mathrm{Cu}, \mathrm{Pb}, \mathrm{Cd}$ and $\mathrm{Cr}$ ) and total hydrocarbons (THC) in the water and tissues (gills, intestine and muscle) of an abundant and economically significant fish (Clarias gariepinus) harvested from Osse River were investigated from April, 2014 to September, 2015. Water and fish samples were collected from 4(four) chosen stations and were analysed for the levels of heavy metals and total hydrocarbons. The ecological risk of the study area and health risk indices of the fishes were assessed. Generally, accumulation of heavy metals and total hydrocarbons in the fish was gills > intestine > muscles (anomalous sequence). The sequence may pose some threats to the health of the consumers. Iron, zinc, copper, cadmium and THC showed significant health risk indices in the fish despite their insignificant ecological risk indices. Further in-depth study on the actual levels of risks to consumers is recommended.
\end{abstract}

Keywords: Bioaccumulation factor, ecological risk indices, health risk indices, Clarias gariepinus

\section{Introduction}

Heavy metals are persistent, bio-accumulative and toxic micropollutants (PBTs). Though hydrocarbons are not referred to as PBTs; however their eco-physiological toxicity is also noteworthy. Aquatic environments receive heavy metals and hydrocarbons either through biogeochemical processes (natural sources) or anthropogenic activities (human-caused). The major points of interest are the anthropogenic sources e.g. oil spill during crude oil exploration activities. In the event of oil spill, petrogenic heavy metals and petroleum hydrocarbon are released into the aquatic environment, incorporated into the aquatic food chain and they are biomagnified through alimentation, from one trophic strata to the higher; from bottom to the top of biomasses pyramids. This causes disruption of the delicate aquatic ecological equilibrium; culminating in several ecophysiological hazards such as decreased biodiversity of aquatic organisms (Ashraj, 2005; Vosyliene and Jankaite, 2006), sub-lethal effects on finfish and shellfish, and clinical poisoning to the consumers. The fish are the most susceptible group of aquatic fauna to oil spill (Hariprasad and Dayananda, 2013); due to the vulnerability of their niche i.e. fish are at the top of the aquatic food chain; hence they have high tendency to concentrate heavy metals and hydrocarbon from organisms at lower trophic levels.

Indiscriminate consumption of unscreened food items is a major contributing factor to the relatively low average life expectancy in Nigeria which is currently 52.62 years in 2014 (CIA, 2016); particularly due to consumption of contaminated finfish and shellfish from polluted rivers mainly in the Niger Delta areas of Nigeria. Various anthropogenic activities such crude oil exploration and production, agricultural practices, laundering, dumping of domestic solid wastes etc. release pollutants into Osse River and the aquatic fauna therein are liable to accumulate these chemicals; which finally get to consumers of the fish through consumption. Fishes (mainly Clarias gariepinus) of Osse River are major source of their protein requirements and income generation through trade. It is therefore imperative to subject the fishes to standard screening in order to ascertain the levels of risk the allocthonous chemicals (heavy metals and total hydrocarbon) pose to the environment and the consumers of the fish. This stresses the need for risk characterization; which is the link between risk assessment and risk management. However, the risk indices are function of the octanol/ water partition coefficients or bioaccumulation factors of the chemicals in the tissues of the fishes.

Bio-accumulation of a dissolved contaminant refers to the increased contaminant concentration within an organism; which results from the passive partitioning of the contaminant between the aqueous phase and the lipid compartment of the organism. The extent of bioaccumulation is measured by the bioaccumulation factor (BAF); which is the ratio of the wet weight concentration of a contaminant in an organism and the concentration in the ambient water. Understanding the dynamic process of bio-accumulation is very essential in protecting human beings and other organisms from the adverse effects of contaminant exposure. It is also an effective tool 
in regulation of contaminants such heavy metals and total hydrocarbon (OECD, 2003). The aim of the study was to evaluate the ecological risk quotients of the study area and 14 health risk indices of Clarias gariepinus.

\section{Materials And Methods}

\subsection{Study Area}

The study area is a stretch of Osse River; between Benin River and Ughoton streams. The river flows in south westerly direction through Nikorowa, Ekewan, Gelegele, and Izedema communities. It is a fresh oligotrophic (Imoobe and Adeyinka, 2009) lotic freshwater, with a thick vegetation canopy along most part of its bank. It is located in the Ovia North- East local of area of Edo State; in the tropical rainforest belt of southern Nigeria. The river lies between $5^{\circ} 16^{\prime} 40^{\prime \prime} \mathrm{E}$ and $5^{\circ} 23^{\prime} 20^{\prime \prime} \mathrm{E} ; 6^{\circ} 2^{\prime} 0^{\prime \prime} \mathrm{N}$ and $6^{\circ} 14^{\prime} 0^{\prime \prime} \mathrm{N}$. A detailed description of the hydrological and drainage, climatic and catchment edaphic features of Osse River has been documented (Ogbeibu and Omoigberale, 2005; Omoigberale and Ogbeibu, 2007).

Four (4) stations were designated at strategic locations along the course of the river; for the purpose of this research. Station 1 (Control station) at Nikorowa, Station 2 (Ekehuan), Station 3 (Gelegele) and Station 4 (Iziedema) were chosen (Fig. 1). Distinguished anthropogenic activities take place at strategic sections of the river; which were chosen as stations. There was minimal or negligible activity at Nikorowa (Station 1; control 8 station). Innumerable vessels of locally refined diesel were transported to and stored at 9 the bank of Ekehuan section (Station 2); 4,135 metres downstream from Station 1. Dubril Oil Company carries out oil exploration and production activities at the Gelegele section (Station 3); 4, 441 metres downstream from Station 2. While immense lumbering activities take place at the bank of the Iziedema section (Station 4) of the river; 1, 400 metres downstream from Station 3.

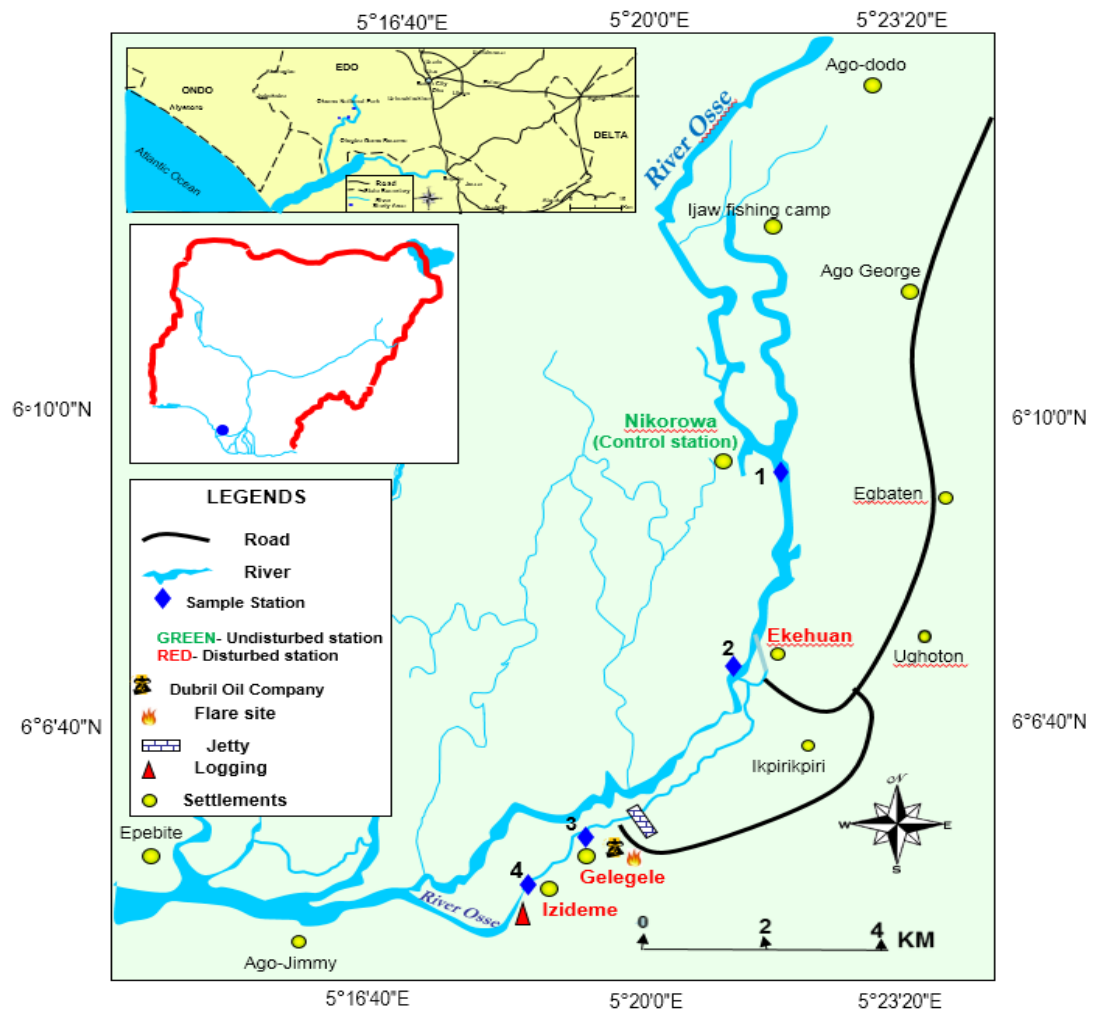

Figure 1: The Study Area

\subsection{Collection and analysis of samples}

For a period of 18 months (April, 2013 to September, 2014) water samples were collected at all stations using standard methods. The $\mathrm{pH}$ of water was taken and recorded in-situ using a WTW water sampler probe. All samples were transported immediately to the laboratory for analysis of the physico-chemical variables which were recorded in $\mathrm{mg} / \mathrm{L}$; using standard methods (APHA, 1998). Total petroleum hydrocarbon in water samples were analyzed using an infrared spectrophotometer (IR-Spec) at a wavelength of about $3.425 \mu \mathrm{m}$.

Six (6) replicates of Clarias gariepinus samples were collected across the stretch of the river using fishing nets, baskets and hooks. They were preserved in ice coolers and taken to the laboratory for proper identification using standard references (Olaosebikan and Raji, 1998; and Idodo-Umeh, 2003). The gills, intestine and muscles of the fish were collected in sterile sample bottles, labeled and preserved in the freezer for 
digestion and analysis of heavy metals and total hydrocarbons. 0.8 grams of each fish tissue sample (gills, intestine and muscle) was dried at $105^{\circ} \mathrm{C}$ to a constant weight. Each dried sample was ground, using porcelain mortar and pestle. The ground fish tissues were transferred to a porcelain basin and put into a Thermicon $\mathrm{P}$ muffle furnace at a temperature of $550{ }^{\circ} \mathrm{C}$ for $4 \mathrm{hrs}$. Samples were digested with tri-acid 8 mixture (HNO3:HClO4:H2SO4 = 10:4:1) at a rate of $5 \mathrm{ml}$ per $0.5 \mathrm{~g}$ of sample and was placed on a hot plate at $100{ }^{\circ} \mathrm{C}$ temperature. Digestion continued until the liquor became 10 clear. The digested liquor was filtered through Whatmann 541 filter paper and diluted to $25 \mathrm{ml}$ with distilled water of the element in the sample solution times as additional factor in $\mu \mathrm{g} / \mathrm{g}$ dry weight. Metals $(\mathrm{Mn}, \mathrm{Zn}, \mathrm{Cu}, \mathrm{Pd}, \mathrm{Cd}, \mathrm{Cr}$; except Fe) were determined using Atomic Absorption Spectrophotometer (UNICAM 929); as illustrated by APHA (1998). Iron concentration was determined using Orthophenantroline method; as illustrated by Oguzie and Izevbigie (2009).

\subsection{Statistical analysis}

The obtained water and specimen data were analysed using SPSS package (version 19.0) and the descriptive statistics were expressed as mean \pm standard deviation and range; using one way analysis of variance (ANOVA) to test for the significant difference among the groups at probability level of 0.05 . Furthermore, Duncan multiple range test was employed in ascertaining the actual locations of the significant differences; still 22 maintaining probability level of 0.05 .

\subsubsection{Risk characterization}

Health Risk Index for heavy metals was calculated thus;

Health Risk Index $($ HRI $)=\quad$ Estimated daily intake or daily intake of metal (DIM)

Acceptable daily intake or reference oral dose

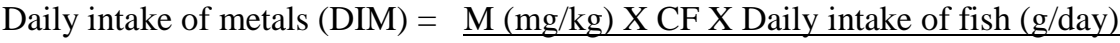

Average body weight $(\mathrm{kg})$

Where $\mathrm{CF}$ is Conversion factor $=0.085, \mathrm{M}$ is the metal concentration in the fish tissue, $60 \mathrm{~kg}$ was adopted as the average body weight. The fish consumption rate in Nigeria is $48 \mathrm{~g} / \mathrm{person} /$ day.

The health risk index of total hydrocarbons was calculated thus;

$$
\mathrm{HRI}=\mathrm{C} \times \frac{\mathrm{IR} \times \mathrm{EF} \times \mathrm{ED}}{\mathrm{BW} \times \mathrm{AT}} \times \mathrm{SF} \times \mathrm{ADAF}
$$

Where $\mathrm{C}=$ concentration of carcinogen in fish tissues $(\mathrm{mg} / \mathrm{kg})$

$\mathrm{IR}=$ intake rate of fish; which is $48 \mathrm{~g} /$ person/day.

$\mathrm{BW}=$ average body weight of exposed individuals $(60 \mathrm{~kg})$

$\mathrm{EF}=$ exposure frequency; how many times the individuals are exposed to these carcinogens in a year. The adopted value is 365 days/ year.

$\mathrm{ED}=$ Exposure Duration; which is the adopted value of the average life expectancy of a Nigerian; which is 52.62 years in 2014 (CIA, 2016).

$\mathrm{AT}=$ length of time over which the average dose was calculated; which is 365 days $\mathrm{X} 52.62$ years

$\mathrm{SF}=$ Slope factor; which is $2.0(\mathrm{mg} / \mathrm{kg} \text {-day })^{-1}$

$\mathrm{ADAF}=$ Age-dependent adjustment factor. The adopted value is 1 .

Concentrations of chemicals above permissible limits in the aquatic environment elicit high levels of ecological risks. These risks have to be numerically evaluated for quantification and interpretation.

Ecological risk assessment was therefore calculated thus;

Risk Quotient $(\mathrm{RQ})=$ Environmental concentration $(\mathrm{mg} / \mathrm{kg})$

Recommended limit $(\mathrm{mg} / \mathrm{kg})$

\section{Results And Discussion}

Water quality characteristics is of high importance in the study of dynamics of heavy metals and total hydrocarbon in the aquatic ecosystem; which can be assessed through monthly sampling (Imoobe, 1997). The concentrations of the parameters analysed in the water samples were all lower than the regulatory limits (Table 1). The concentrations of iron, zinc and chromium in water of Stations 2, 3, and 4 were very much significantly than that of Station $1(\mathrm{P}<0.001)$. This can be attributed to the various anthropogenic activities at the different stations, except Station 1; which is the control station. Significant differences across the stations in all other parameters analysed; in comparison with the control station (Station 1). These indicate a significant alteration in the background levels by the anthropogenic activities. Although the levels of the parameters were within 
acceptable limits; suggesting that the water of the river supports aquatic flora and fauna. The overall result quite agrees with the earlier observations of the river by Omoigberale and Ogbeibu (2010); within the period of July, 2000 and June, 2002, and Oguzie and Ehigiator (2011) within the period of July to September, 2007. The gills was the most preferred site of accumulation due to the fact that the gills are endowed with physiological and anatomical properties that maximize absorption efficiency (Table 2). This quite agrees with the findings of Eneji et al., (2011).

The sequence of heavy metals and total hydrocarbon in descending order in Clarias gariepinus of the river $($ Fig. 2) was $\mathrm{Fe}(6.38 \%)>\mathrm{Zn}(18.97 \%)>\mathrm{Mn}(7.89 \%)>\mathrm{Cu}(4.15 \%)>\mathrm{Cr}(2.55 \%)>\mathrm{THC}(0.81 \%)>\mathrm{Pb}$ $(0.2 \%)>\mathrm{Cd}(0.05 \%)$ and that of the water (Fig. 3) was THC $(24.7 \%)>\mathrm{Fe}(23.6 \%)>\mathrm{Zn}(12.5 \%)>\mathrm{Mn}(11.7 \%)$ $>\mathrm{Cr}(8.5 \%)>\mathrm{Pb}(8.3 \%)>\mathrm{Cu}(6.2 \%)>\mathrm{Cd}(4.5 \%)$. This shows that the tissues of the fish had affinity for copper; which overtook the position of chromium in the sequence observed in the fish. The tissues of the Claris gariepinus of the river had the highest affinity for iron; this can be attributed to the importance of the metal in the haemoglobin; required in respiration. The trend of the parameters observed in the fish can generally be attributed to the threshold of essentiality of these metals. However, this observation is at variance with the findings of Eneji (2010) in the Clarias gariepinus of River Benue; which was $\mathrm{Cr}>\mathrm{Zn}>\mathrm{Fe}>\mathrm{Cu}>\mathrm{Mn}>\mathrm{Cd}>$ $\mathrm{Pb}$. Iron, zinc, copper, cadmium and total hydrocarbon had significant health risk indices in the fish (Fig. 4); despite the fact that only manganese posed significant ecological risk (Fig. 5). This can be attributed to the high bioaccumulation factors of these chemicals in the tissue of the fish (Fig. 6). This implies that the bioaccumulation factors; also referred to as the octanol/ water partition coefficients (Log Kow) may cause chemicals of low concentrations in the aqueous phase to rise to dangerous levels in biota (Camusso et al., 1995).

Distribution of heavy metals and total hydrocarbon in the tissues of Clarias gariepinus was in the order of: Gills $(55 \%)>$ Muscle $(27 \%)>$ Intestine $(18 \%)$. The contaminants had the highest affinity for the gills of Clarias gariepinus; followed by the muscles, then the intestine (Fig.7). This is an anomalous order; as against the normal order: gills > intestine > muscle (Eneji et al., 2011; Akan et al., 2012). Under normal circumstances, the gill is expected to accumulate the highest concentrations amongst the tissues. This is due to the fact that the gills is endowed with physiological and anatomical properties that maximize absorption efficiency. The gill also plays outstanding physiological roles of iono-regulation, osmo-regulation and respiration; hence interacts more with chemicals in the water phase than other tissues. Asides all these, the gills is the first target of entry of these contaminants in fish. The intestine on the other hand, is expected to accumulate higher levels of these contaminants than muscle because the intestine is more metabolically active than the muscle. Contrary to these expectations, the muscles tissue of Clarias gariepinus of Osse River overtook the position of the intestine (second position) in the accumulation order (Fig. 7). The muscle tissue is the major edible part of fish and constitutes the major part of its body weight (Fabbri et al., 1998); hence holds its nutritional and economic values. The implication of this is that the level of accumulation of heavy metals and total hydrocarbon in the muscle tissue of Clarias gariepinus of the river having overtaken that of the intestine, threatens to be of worse health implications to the consumers than expected (Reinfelder et al., 1998). This unusual order, hereby termed critical or anomalous order of tissue contamination was however observed in silver catfish (Chrysichthys nigrodigitatus) and Tilapia nilotica of Okumeshi River, Delta State, Nigeria (Ekeanyanwu et al.,2010); and also in Chrysichthys nigrodigitatus and Tilapia zilli of Badagry creek, Lagos, Nigeria by Aderinola et al., (2012).

TABLE 1. Summary of physico-chemical parameters of the water of Osser River between April, 2013 and September, 2014

\begin{tabular}{|c|c|c|c|c|c|c|}
\hline PARAMETERS & STATION 1 & STATION 2 & STATION 3 & STATION 4 & P-VALUE & FMEnv Limit \\
\hline $\mathrm{Fe}(\mathrm{mg} / \mathrm{L})$ & $0.45 \pm 0.16^{\mathrm{B}}(0-2.4)$ & $1.71 \pm 0.25^{A}(0-3.5)$ & $1.44 \pm 0.19^{A}(0-2.9)$ & $1.38 \pm 0.27^{A}(0.2-5.4)$ & $P<0.001$ & 20 \\
\hline $\mathrm{Zn}(\mathrm{mg} / \mathrm{L})$ & $0.14 \pm 0.03^{\mathrm{B}}(0-0.4)$ & $0.59 \pm 0.15^{A}(0.1-2.6)$ & $0.92 \pm 0.3^{A}(0.2-5.2)$ & $0.985 \pm 0.25^{A}(0-3.3)$ & $\mathrm{P}<0.05$ & 1 \\
\hline $\mathrm{Cu}(\mathrm{mg} / \mathrm{L})$ & $0.02 \pm 0.01^{\mathrm{B}}(0-0.1)$ & $0.14 \pm 0.03^{\mathrm{B}}(0-0.5)$ & $0.13 \pm 0.02^{\mathrm{B}}(0-0.4)$ & $1.05 \pm 0.26^{A}(0-2.76)$ & $\mathrm{P}<0.001$ & $<1$ \\
\hline $\mathrm{Pb}(\mathrm{mg} / \mathrm{L})$ & $0.01 \pm 0.003^{\mathrm{B}}(0-0.1)$ & $0.08 \pm 0.01^{\mathrm{B}}(0-0.2)$ & $0.83 \pm 0.24^{A}(0-2.7)$ & $0.83 \pm 0.26^{A}(0-2.7)$ & $\mathrm{P}<0.001$ & $<1$ \\
\hline $\mathrm{THC}(\mathrm{mg} / \mathrm{L})$ & $0.02 \pm 0.01^{\mathrm{D}}(0-0.1)$ & $3.19 \pm 0.6^{A}(0-10.5)$ & $0.77 \pm 0.2^{\mathrm{B}}(0-1.89)$ & $1.26 \pm 0.28^{\mathrm{C}}(0-3.2)$ & $\mathrm{P}<0.001$ & 10 \\
\hline
\end{tabular}

Note: Values with similar superscript letters have no significant difference

$\mathrm{N}=$ number of sample replicates. $\mathrm{P}>0.05$ means there is no significant difference, $\mathrm{P}<0.05$ means there is significant difference, $\mathrm{P}<0.01$ means there is much significant difference, and $\mathrm{P}<0.001$ means there is very much significant difference.

TABLE 2. Summary table of heavy metals and the total hydrocarbons in Clarias gariepinus

\begin{tabular}{|c|c|c|c|c|}
\hline \multirow{2}{*}{ PARAMETERS } & GILLS & INTESTINE & MUSCLE & P-VALUE \\
\cline { 2 - 3 } & $\begin{array}{c}\text { MEAN } \pm \text { S.E } \\
\text { (RANGE), }\end{array}$ & $\begin{array}{c}\text { MEAN } \pm \text { S.E } \\
\text { (RANGE), }\end{array}$ & $\begin{array}{c}\text { MEAN } \pm \text { S.E } \\
\text { (RANGE), }\end{array}$ & \\
\hline
\end{tabular}


Assessment of some heavy metals and total hydrocarbons in Clarias gariepinus fish of Osse River, ..

\begin{tabular}{|c|c|c|c|c|}
\hline & $\mathrm{N}=18$ & $\mathrm{~N}=18$ & $\mathrm{~N}=18$ & \\
\hline $\mathrm{Fe}(\mathrm{mg} / \mathrm{L})$ & $\begin{array}{c}281.8 \pm 42.3^{A} \\
(21-658)\end{array}$ & $\begin{array}{c}66.1 \pm 7.8^{\mathrm{B}} \\
(15.5-153)\end{array}$ & $\begin{array}{l}116.8 \pm 18.7^{\mathrm{B}} \\
(15.8-242.4)\end{array}$ & $P<0.001$ \\
\hline $\mathrm{Mn}(\mathrm{mg} / \mathrm{L})$ & $\begin{array}{l}24.1 \pm 5.1^{A} \\
(1.7-62.3)\end{array}$ & $\begin{array}{l}10.5 \pm 2.7^{B} \\
(1.1-37.4)\end{array}$ & $\begin{array}{l}21.5 \pm 2.5^{\mathrm{A}} \\
(1.3-35.1)\end{array}$ & $P<0.05$ \\
\hline $\mathrm{Zn}(\mathrm{mg} / \mathrm{L})$ & $\begin{array}{l}57.8 \pm 6.8 \\
(10-117)\end{array}$ & $\begin{array}{c}38.9 \pm 7.5 \\
(7-118)\end{array}$ & $\begin{array}{c}38.1 \pm 5.5 \\
(7-83)\end{array}$ & $\mathrm{P}>0.05$ \\
\hline $\mathrm{Cu}(\mathrm{mg} / \mathrm{L})$ & $\begin{array}{l}14.9 \pm 2.6^{A} \\
(2.2-45.6)\end{array}$ & $\begin{array}{c}8 \pm 1.4^{B} \\
(0.6-20.5)\end{array}$ & $\begin{array}{c}6.6 \pm 1.2^{B} \\
(1-14)\end{array}$ & $P<0.01$ \\
\hline $\mathrm{Pb}(\mathrm{mg} / \mathrm{L})$ & $\begin{array}{c}1.1 \pm 0.2^{A} \\
(0-3)\end{array}$ & $\begin{array}{c}0.2 \pm 0.03^{B} \\
(0-0.4)\end{array}$ & $\begin{array}{c}0.1 \pm 0.03^{\mathrm{B}} \\
(\mathbf{0 - 0 . 4 )}\end{array}$ & $P<0.001$ \\
\hline $\mathrm{Cd}(\mathrm{mg} / \mathrm{L})$ & $\begin{array}{c}0.1 \pm 0.02 \\
(0-0.1)\end{array}$ & $\begin{array}{c}0.1 \pm 0.02 \\
(0-0.6) \\
\end{array}$ & $\begin{array}{c}0.2 \pm 0.09 \\
(0-1.6) \\
\end{array}$ & $\mathrm{P}>0.05$ \\
\hline $\mathrm{Cr}(\mathrm{mg} / \mathrm{L})$ & $\begin{array}{c}6.4 \pm 1.3 \\
(0.01-18.5)\end{array}$ & $\begin{array}{l}4.4 \pm 0.8 \\
(0-11.4) \\
\end{array}$ & $\begin{array}{c}7.331 \pm 1.756 \\
(0-23.03)\end{array}$ & $P>0.05$ \\
\hline THC (mg/L) & $\begin{array}{l}3.5 \pm 0.5^{\mathbf{A}} \\
(0.6-8.2)\end{array}$ & $\begin{array}{l}1.6 \pm 0.2^{\mathrm{B}} \\
(0.3-3.5)\end{array}$ & $\begin{array}{l}0.6 \pm 0.2^{\mathrm{C}} \\
(0.2-2.3)\end{array}$ & $P<0.001$ \\
\hline
\end{tabular}

Note: Values of same superscript letters have no significant difference

$\mathrm{N}=$ number of sample replicates, $\mathrm{P}>0.05$ means there is no significant difference, $\mathbf{P}<\mathbf{0 . 0 5}$ means there is significant difference, $\mathbf{P}<\mathbf{0 . 0 1}$ means there is much significant difference, $\mathbf{P}<\mathbf{0 . 0 0 1}$ means there is very much significant difference

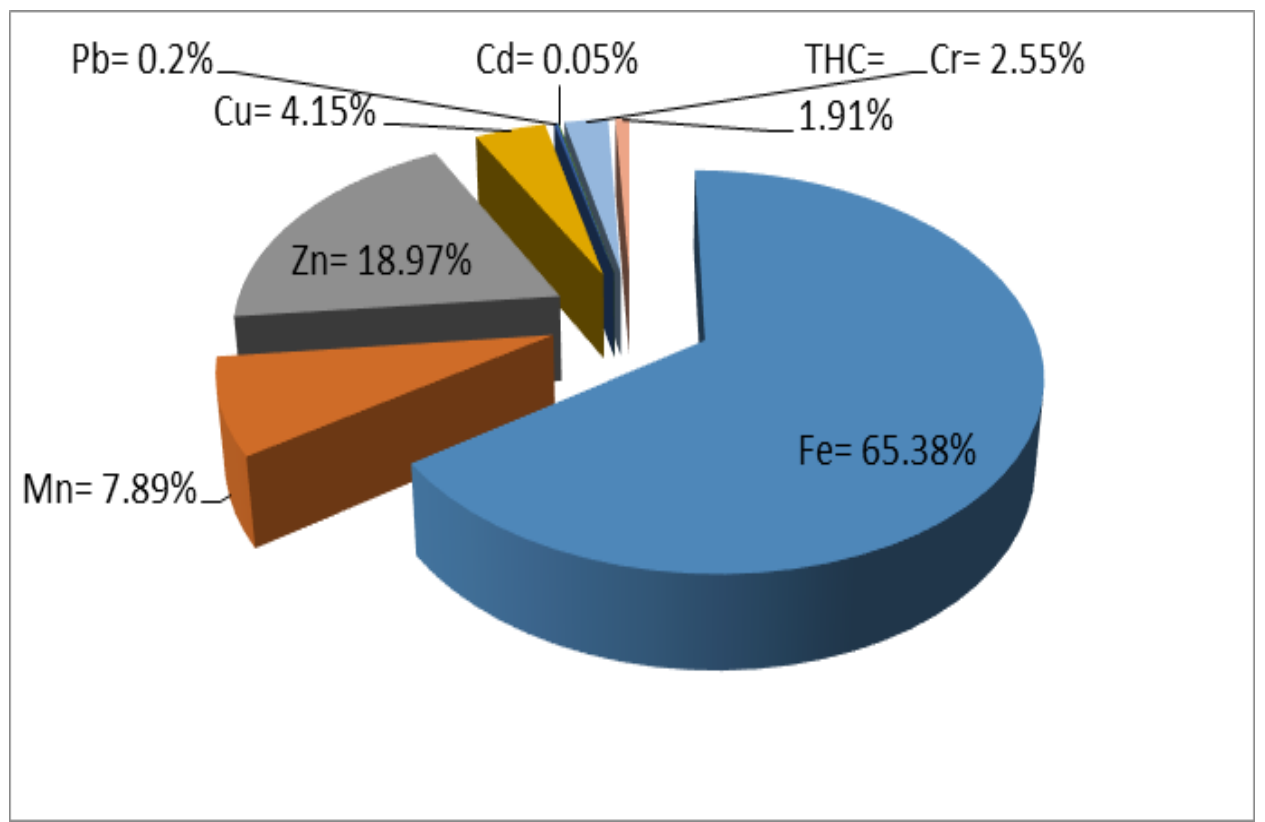

Figure 2: Percentage composition of heavy metals and total hydrocarbon in fish 


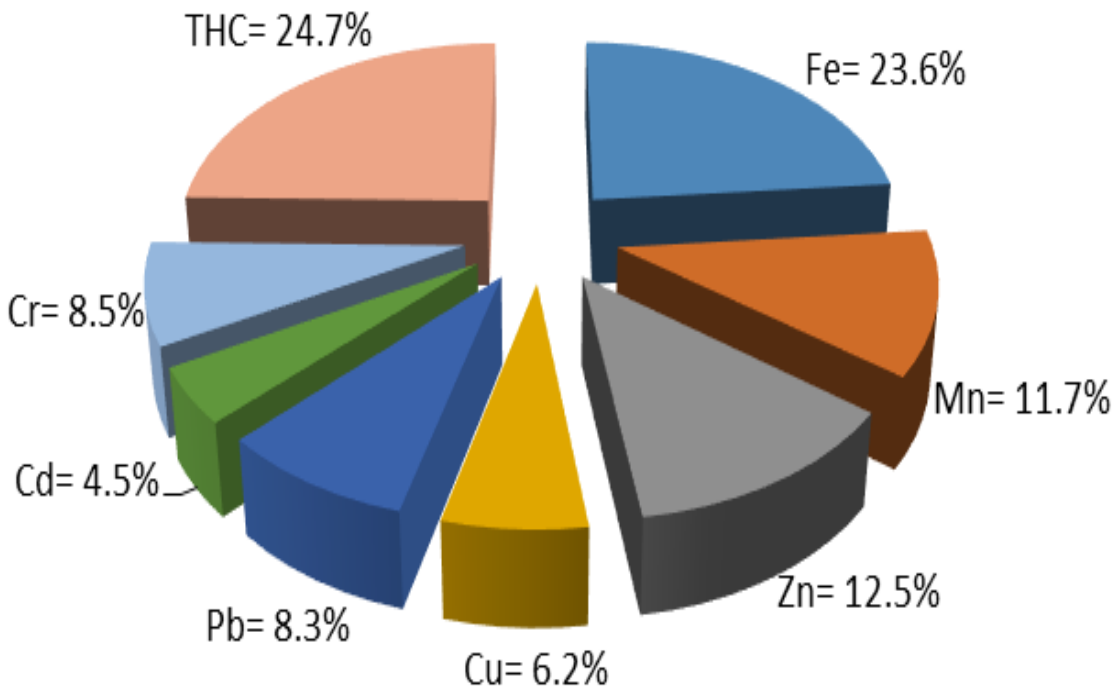

Figure 3: Percentage composition of heavy metals and total hydrocarbon in water

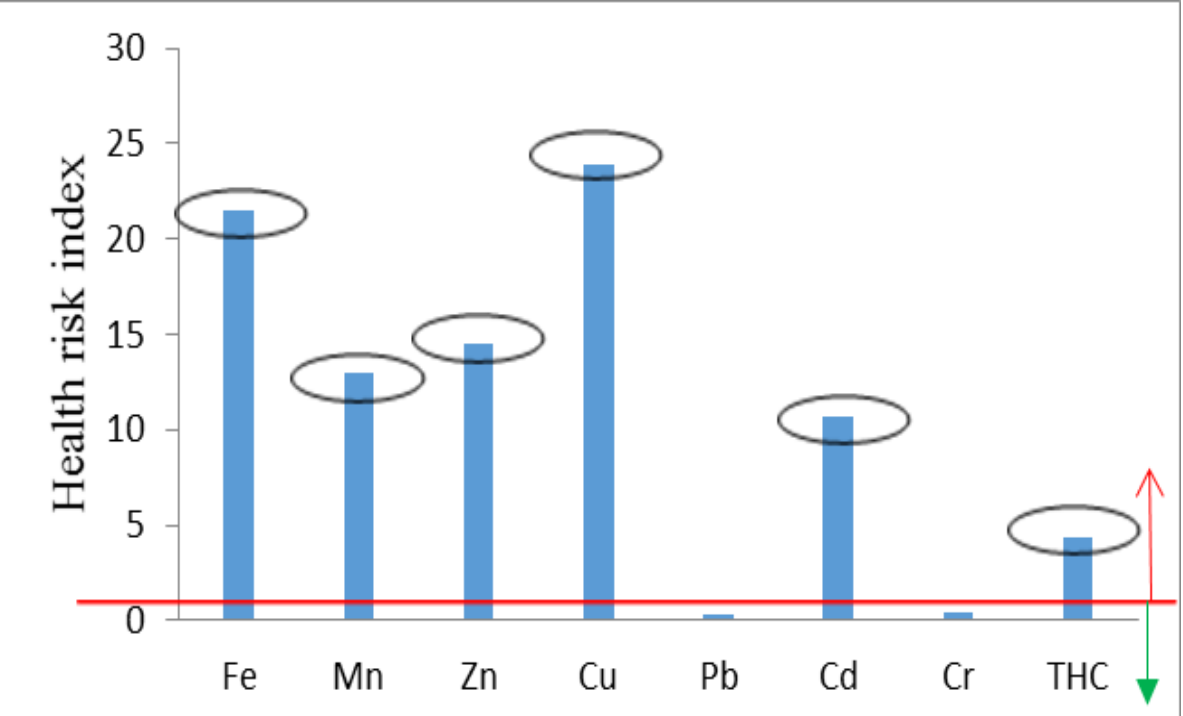

Figure 4: Health risk indices in Clarias gariepinus 


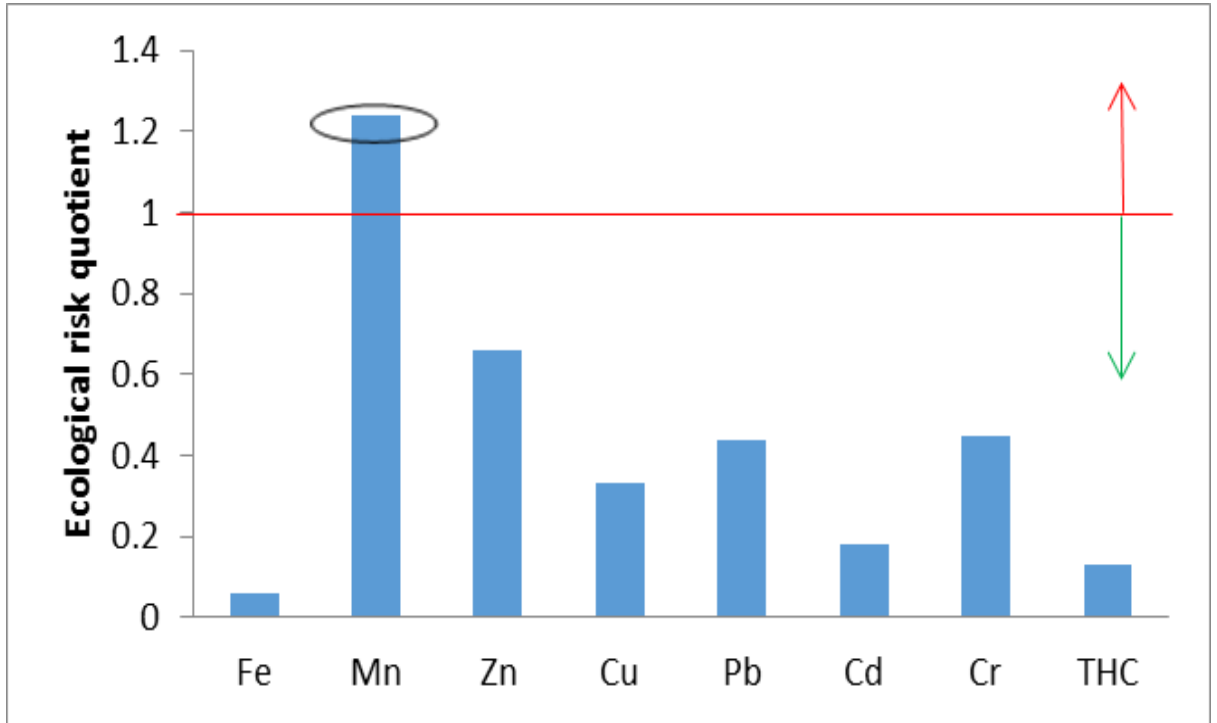

Figure 5: Ecological risk quotient

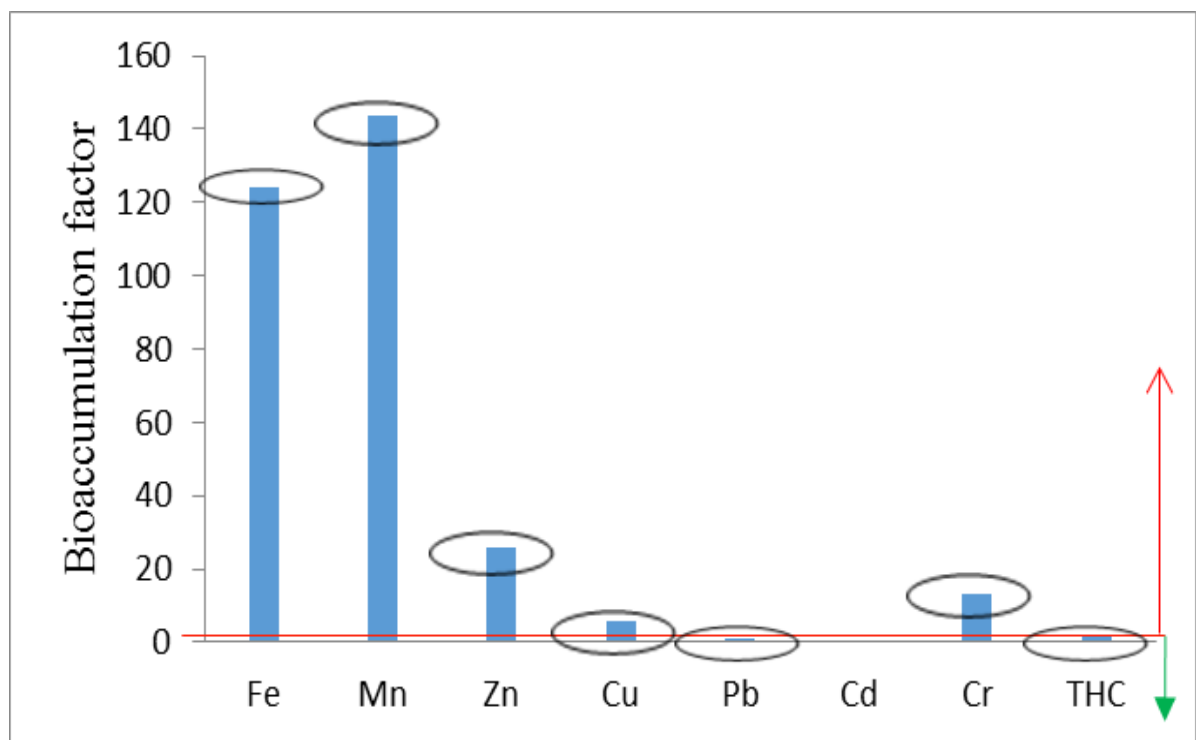

Figure 6: Bioaccumulation factor (BAF) in Clarias gariepinus

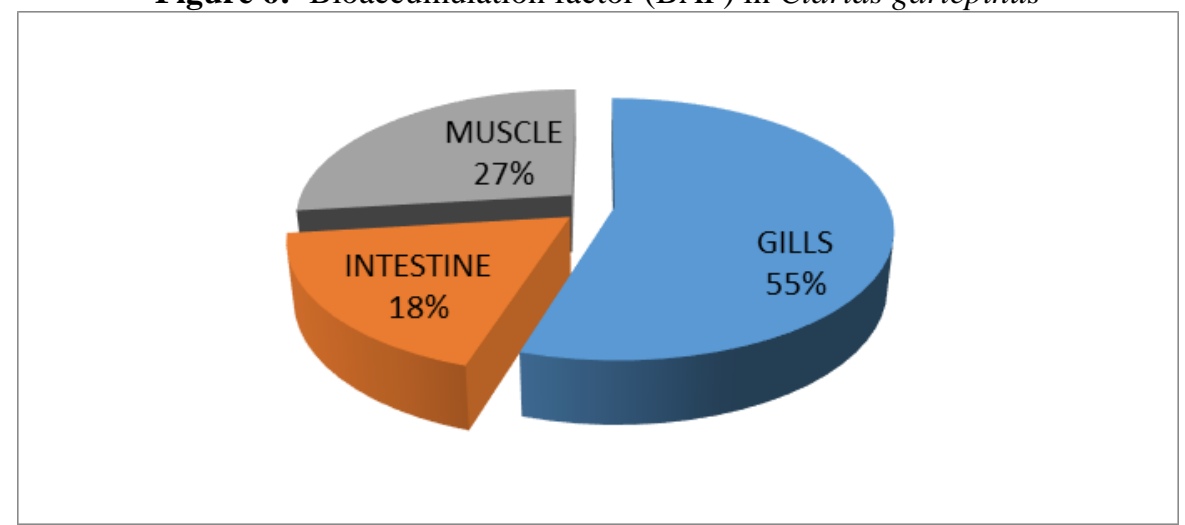

Figure 7: Percentage distribution of heavy metals and total hydrocarbon in tissues of fish

\section{Conclusion}

The water of Osse River is of no ecological risk to the aquatic life and it is suitable for domestic use. However the Clarias gariepinus of the river may pose some levels of chronic threats to the consumers. Worse still is the outstanding contamination of the muscle which is the edible part. We hereby recommend further indepth study in order to ascertain actual risks consumption of the fishes may pose to the health of the consumers; 
as well as factors responsible for anomalous order of tissue contamination. Regulation of anthropogenic activities, immediate standard remediation processes and constant bio-monitoring studies of the aquatic environment are highly recommended. Further deeper studies to ascertain the actual levels of risks to consumers is imperative.

\section{Acknowledgements}

A big gratitude is reserved for the parents of the Corresponding Author; Chief and Mrs. W.P.O. Isibor for their selfless financial support and immeasurable love. We all appreciate the support of Dr. Abdulrahman Dirisu (Animal and Environmental Biology, University of Benin) for providing necessary information about the study area. This gave us a substantial congnizance; which influenced our decisions in the research design.

\section{References}

[1]. W. Ashraj. Accumulation of heavy metals in kidney and heart tissues of Epinephelus micodon fish from the Arabian Gulf. Environmental Monitoring Assessment, 1-3(103), 2005, pp 311- 316.

[2]. M.Z. Vosyliene, and A. Jankaite. Effect of heavy metal model mixture on Rainbow trout biological parameters. Ekologija, 2006, pp12-18.

[3]. N.V. Hariprasad, and H.A. Dayananda. Environmental Impact due to Agricultural runoff containing Heavy metal- A Review. International Journal of Scientific and Research Publications, Volume 3, Issue 5, 2013, pp 224- 280.

[4]. Organization for Economic Cooperation and Development (OECD). Pesticides persistent, bio accumulative and toxic pesticides in: OECD Member countries results of survey on data requirements and risk assessment approaches. Environment, health and safety publications series. 15, 2013, $1-67$.

[5]. T.O.T. Imoobe, and M.L. Adeyinka. Zooplankton-based assessment of the trophic state of a tropical forest river in Nigeria. Arch. Biol. Sci. Belgrade, 61 (4), 2009, 733- 740.

[6]. A.E. Ogbeibu, and M.O. Omoigberale. Environmental impacts of oil exploration and production on the Rotifers of Osse River, Southern Nigeria. African Journal of Environmental Pollution \& Health 4(1), 2005, 72- 80.

[7]. M.O. Omoigberale, and A.E. Ogbeibu. Assessing the environmental impacts of oil exploration and production on the water quality of Osse River, Southern Nigeria. Global Journal of Environmental Sciences. 6(1), 2007, 1- 13.

[8]. American Public Health Association (APHA). Standard Methods for Examination of Water and Waste water. 20th edition APHA AWNA- WPCF. New York, USA, 1998, pp 113- 414.

[9]. B.D. Olaosebikan, and A. Raji A. Field Guide to Nigerian Freshwater Fishes. Federal College of Freshwater Fisheries Technology. 1998, Pp 52 and 75.

[10]. G. Idodo-Umeh, G. Freshwater Fishes of Nigeria (Taxonomy, Ecological notes, Diet and Utilization). Idodo Umeh Publishers Limited, 2003, Pp 408

[11]. F.A. Oguzie, and E.E. Izevbigie. A study of heavy metals concentration in the sediments upstream of Ikpoba River and Reservoir in Benin City, Nigeria. Bioscience Res. Comm. 21 (3), 2009, 119- 127.

[12]. Central Intelligence Agency (CIA). World Factbook, CIA Prinitng Press, 2016, Pp 17.

[13]. T.O.T. Imoobe. Crustacean of Jamieson River, Nigeria. Ph. D. Thesis, University of Benin, Benin City, Nigeria. 1997, Pp 155.

[14]. M.O. Omoigberale, and A.E. Ogbeibu. Environmental impacts of oil exploration and production on the Macrobenthic Invertebrate Fauna of Osse River, Southern Nigeria. Research Journal of Environmental Sciences. 4, 2010, $101-114$

[15]. F.A. Oguzie, and F.A.R. Ehigiator. Concentration of heavy metals in three African Prawn (Crustacea: Palaemonidae) from Osse river in Edo State, Nigeria. J. Agric. Sc. Env. 11 (1), 2011, 104- 113.

[16]. S.I. Eneji, S.A. Rufus, and P.A. Annune. Bioaccumulation of Heavy Metals in Fish (Tilapia Zilli and Claria gariepinus) Organs from River Benue, North-Central Nigeria. Pak. J. Anal. Environ. Chem. Vol. 12, No. 1 \& 2, 2011, 25-31.

[17]. S.I. Eneji. Spatial and temporal variation in the heavy metals loading of River Benue in Makurdi metropolitan area, Ph. D. Thesis, Department of Chemistry University of Agriculture Makurdi, Nigeria. 2010.

[18]. M. Camusso, L. Vigano, and R. Baistrini. Bioaccumulation of trace metals in rainbow trout. Ecotoxicology and Environmental Safety, 31: 1995, 133-141.

[19]. J.C. Akan, M. Salwa, B.S. Yikala, and Z. M. Chellube. Study on the Distribution of Heavy Metals in Different Tissues of Fishes from River Benue in Vinikilang, Adamawa State. British Journal of Applied Science \& Technology, 2(4): 2012, $311-333$.

[20]. E. Fabbri, A. Capuzzo, and T.W. Moon. The role of circulating catecholamines in the regulation of fish metabolism: An overview, Comp. Biochemical Physiology Pharmacology Toxicology Endocrinology. 1(20), 1998, 177- 192.

[21]. J.R. Reinfelder, N.S. Fisher, S.N. Lumona, J.W. Nichols, and W.X.Wang. Trace elements 19 trophic transfer in aquatic organisms: a critique of the kinetic model approach. Science 20 of the Total Environment. 219: 1998, 217- 315.

[22]. C.R. Ekeanyanwu, C.A. Ogbuinyi, and O.F. Etienajirhevwe. Trace Metals Distribution in Fish Tissues, Bottom Sediments and Water from Okumeshi River in Delta State, Nigeria. 3(3), 2010, 12 - 17.

[23]. O.J. Aderinola, V. Kusemiju, E.O. Clarke, M.A. Anetekhai, and A.A. Adu. Bioaccumulation of heavy metals in Silver catfishChrysichthys nigrodigitatus, Tilapia zillii and Macrobrachium macrobrachion caught in Badagry creek, Lagos, Nigeria. Transnational. Journal of Science and Technology. 2 (7), 2012, 34- 47. 